\title{
Research on the coupling coordinative degree of tourism development and poverty alleviation effects in china based on the model of DPSIR-- an example of Guizhou
}

\author{
Yanling Ma \\ School of Management (Business School), Zunyi Normal College, \\ Zunyi, Guizhou 563002, \\ China
}

Received: July 5, 2020. Revised: September 7, 2020. 2nd Revised: September 23, 2020. Accepted: September 29, 2020. Published: September 30, 2020.

\begin{abstract}
Based on the framework of driving forcepressure-state-response, a DPSIR framework for the coupling and coordination mechanism between tourism development and poverty alleviation effects was constructed by comprehensively considering the poverty alleviation process and poverty vulnerability characteristics of Guizhou Province. On this basis, by using the data from 2006-2017, the paper made an empirical analysis on the development relation of tourism development and ecological environment coupling in Guizhou Province by using the coupled model. The results showed that the degree of coupling between tourism development level and poverty alleviation effects showed multiple different stages as human production activities progress. The comprehensive evaluation index of tourism development and poverty alleviation effects in Guizhou Province showed an upward trend from 2012 to 2019, and the rate of increase was fast. The degree of coupling was continuously rising rapidly, experienced two stages: Firstly, the period from the severe imbalance period to the imminent imbalance period from 2012 to 2013. Secondly, the imbalance period to the primary coordination period from 2014 to 2016. Lastly, the primary coordination period to the good coordination period from 2017 to 2019. A transition from a serious imbalance to a wellcoordinated phase was achieved. According to the different developmental stages of the coupling coordination mechanism, we put forward some measures for the coordinated development between tourism development and poverty alleviation effects in Guizhou Province.
\end{abstract}

Keywords-Coupling coordinated development, DPSIR model, poverty alleviation effects, tourism development.

\section{INTRODUCTION}

$\Gamma^{\text {HE }}$ report of the 19th National Congress of the Communist Party of China puts forward the strategy of Rural Revitalization for the first time, which calls for accelerating the modernization of agriculture and rural areas by the general requirements of "prosperous industries, ecological livability, rural civilization, effective governance, and wealthy life." [1] As one of the important measures to achieve rural rejuvenation, targeted poverty alleviation is the prerequisite and foundation for achieving rural rejuvenation. China's poor population is mainly concentrated in rural areas. Without the poverty alleviation and prosperity of rural people, there will be no overall revitalization of rural areas [2].

As a major strategy to achieve the goals of the "two hundred years", the strategy of rural vitalization is an important measure for Chinese farmers to get rid of poverty, reduce the gap between urban and rural areas, building a moderately prosperous society, and a modern socialist country in all respects. It provides macro strategic support and innovative ideas for effectively promoting precise poverty alleviation. As achieving the goal of building a well-off society in an all-round way, the current stage of precision poverty alleviation and rural rejuvenation are integrated, influenced, coordinated, and coupled with each other. It is a new theoretical perspective to introduce the coupling theory into the research of poverty alleviation, which will play a positive role in promoting the effect of poverty alleviation and economic development.

Although there are more researches on the coupling and coordination mechanism between the tourism economy and the ecological environment at home and abroad than the correlative research on the relationship between tourism development and poverty alleviation effects. And the study of ecology and poverty and fragile areas in Guizhou is much 
rarer. Therefore, this paper studies the coupling and coordination mechanism between tourism development and poverty effects in typical rocky desertification areas in Guizhou Province, which not only enriches the relevant theories but also provides relevant suggestions for further developing the tourism industry based on winning the battle against poverty.

\section{THEORETICAL BASIS}

Both in terms of goals, timing, and resource allocation, there are certain relationships between tourism development and poverty alleviation work. Firstly, there is coupling on the target. Poor areas and the poor are the biggest shortcomings of building a well-off society in all respects. It means not letting poor people fall behind or leaving a poor area behind. This is the rallying number of the Party Central Committee for the fight against poverty, and it is also the biggest stumbling block to the victory of the fight against poverty [3]. As the main battlefield for poverty alleviation, Guizhou must take multiple measures and vigorously develop tourism. Secondly, it has coupled in timing. With the development of the times, the change of the market and the change of the concept, more and more tourists are no longer satisfied with the traditional sightseeing tour of scenic spots, mountains, and rivers, but gradually turn to all-round in-depth tourism such as leisure tour, holiday tour, experience tour, parent-child tour, etc., taking tourism as an indispensable part of life [4]. Thirdly, it is coupled with resources. With the continuous advancement of poverty alleviation and development, the remaining povertystricken villages and poor people are facing more and more important tasks in poverty alleviation. It is the difficult "hardbone" stage of shuck poverty. These poor areas are often disadvantaged in terms of natural conditions, infrastructure, and population quality. First, the natural conditions are relatively harsh. It is not conducive to the development of modern agriculture because of high mountains, steep slopes, poor land, and difficult farming. It is not conducive to create a convenient and rich recreation and rest space because of the vertical and horizontal gullies, the segmentation of the land, the steep mountains, and the lack of hydrophilicity.

\section{A. Framework and Characteristics}

DPSIR (Driving-Pressure-State-Impact-Response) is an improvement and extension of the traditional concept model of pressure $(\mathrm{P})$, state $(\mathrm{s})$, and response $(\mathrm{R})$ proposed by OECD. In the past, the conceptual model of quality evaluation (that is, PSR) ignored the importance of resources, environment, society, and technology, By comprehensively considering the interaction between the indicators of each link, the operation process of the tourism development system can be described in more detail. This method provides basic and effective model support for domestic and foreign scholars to research resources, environment, socio-economic and other aspects. Study on Fangming Qin's reference, Drawing the conceptual framework of DPSIR for sustainable tourism development, as shown in Fig. 1.

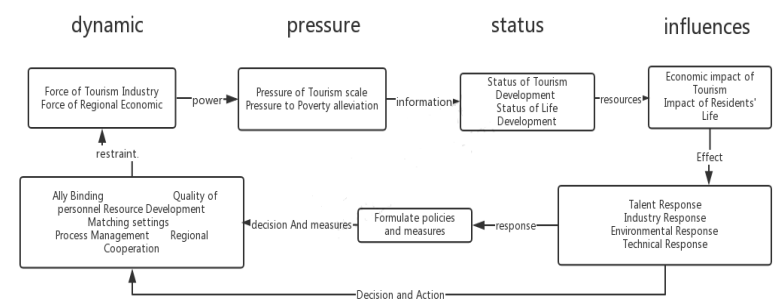

Fig. 1 DPSIR conceptual framework model of tourism development

In the process of coupling and coordinating the effects of tourism development and poverty alleviation. On the one hand, as receivers and receivers, government agencies, enterprises and stakeholders can feel the disharmony and irrationality in the interaction process, such as connection effect, ecological effect, and crowd effect [5]. On the other hand, as the actors of the coordination mechanism and related policymakers and implementers, government agencies, tourism companies, and stakeholders can respond through their behaviors and policy formulation. Based on the interaction between tourism development and poverty alleviation effects. And drawing on the framework of DPSIR, this article constructs a DPSIR framework for tourism development and poverty alleviation effects, as shown in Fig. 2.

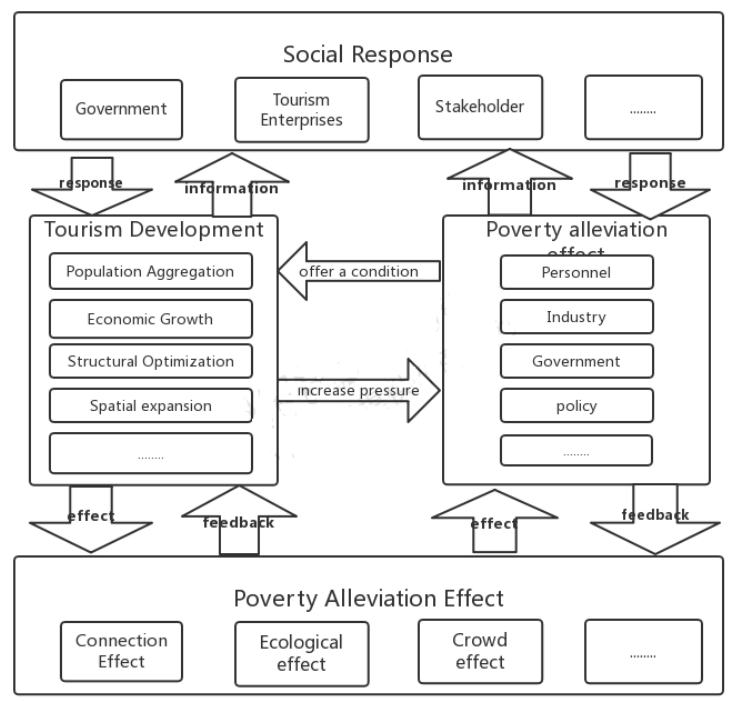

Fig. 2 DPSIR framework for coordination mechanism of tourism development and poverty alleviation effect

\section{Study Design AND MATERIALS}

\section{A. Research Overview}

The development of tourism and anti-poverty is a worldwide research topic, which has always received widespread attention from the international community. Since the 1980s, as an 
effective measure against poverty, tourism poverty reduction has attracted the attention of scholars at home and abroad. At present, it has reached the decisive stage of the battle of poverty alleviation. In the process of vigorously developing tourism resources and developing the tourism industry, what are the effects of poverty alleviation, and what are the problems? According to the characteristics of the development stage of the coupling and coordination mechanism, to promote the development of Guizhou's tourism economy and win Measures to coordinate and coordinate development in the fight against poverty. To put forward measures to promote the development of the tourism economy and fighting against poverty in Guizhou Province. Guizhou has tourism resources such as national culture and red culture all over the province. The "small and special" natural and cultural landscape is everywhere, which meets the resource requirements of smart tourism and the development of tourism in the whole region.

\section{B. Coupling Evaluation Model}

To quantitatively analyze the problem of coupling and coordination between tourism development and poverty alleviation effects. Based on consulting relevant literature and data, this paper uses a physical capacity coupling coefficient model to build a model of coupling and coordination between tourism development and poverty alleviation. Measure and analyze the coupling and coordination The coupling degree model between tourism development and ecological environment is formula (1).

$$
C=\left\{\left(u_{1} \times u_{2}\right) /\left(u_{1} \times u_{2}\right)^{2}\right\}^{\prime 2}
$$

In the formula (1), $\mathrm{C}$ represents a coupling degree, $\mathrm{u}_{1}$ represents a comprehensive development index of the tourism development system, and $\mathrm{u}_{2}$ represents a comprehensive development index of the poverty alleviation effect system. The tourism development system and poverty alleviation effect system belong to two different systems. There are differences in the indicator systems to measure the two systems, which will lead to differences in the development of the two systems. This difference may be manifested in the low level of development of both systems, but the high degree of coupling occurs. To avoid the errors caused by this situation, this paper uses the research of relevant literature [6]. Build a coupling coordination model like (1) and (2).

$$
\begin{aligned}
& D=\sqrt{C \times T} \\
& T=a u_{1}+\beta u_{2}
\end{aligned}
$$

$\mathrm{D}$ represents the coupling coordination of tourism development and poverty alleviation effect; $T$ is the comprehensive evaluation index of tourism development and poverty alleviation effect; $\alpha$ and $\beta$ are undetermined coefficients, and $\alpha+\beta=1$, and $\alpha$ and $\beta$ are assigned respectively $0.5,0.5$. This assignment is because there is a complementary role in the coordinated development of tourism development and the ecological environment. At the same time, for a region, the development of the tourism economy and ecological environment is equally important, so they have the same weight [7-9]. Referring to the research results of Liao Chongbin, Using mean distribution function to divide the interval and level of coupling co scheduling. To reflect the development of tourism and the ecological environment more

\begin{tabular}{|c|c|c|c|}
\hline $\begin{array}{c}\text { Coupling } \\
\text { Coordination } \\
\text { (D) }\end{array}$ & $\begin{array}{l}\text { Standard of } \\
\text { Coupling } \\
\text { Coordination } \\
\text { Degree }\end{array}$ & $\begin{array}{c}\text { Coupling } \\
\text { Coordination } \\
\text { (D) }\end{array}$ & $\begin{array}{l}\text { Standard } \\
\text { of } \\
\text { Coupling } \\
\text { Coordinati } \\
\text { on Degree }\end{array}$ \\
\hline $0.00 \sim 0.09$ & $\begin{array}{c}\text { Extreme imba } \\
\text { lance }\end{array}$ & $0.50 \sim 0.59$ & $\begin{array}{c}\text { Barely coo } \\
\text { rdination }\end{array}$ \\
\hline $0.10 \sim 0.19$ & $\begin{array}{c}\text { Serious } \\
\text { imbalance }\end{array}$ & $0.60 \sim 0.69$ & $\begin{array}{l}\text { Primary } \\
\text { coordinati } \\
\text { on }\end{array}$ \\
\hline $0.20 \sim 0.29$ & $\begin{array}{l}\text { Moderate } \\
\text { imbalance }\end{array}$ & $0.70 \sim 0.79$ & $\begin{array}{l}\text { Intermedia } \\
\text { te } \\
\text { coordinati } \\
\text { on }\end{array}$ \\
\hline $0.30 \sim 0.39$ & $\begin{array}{c}\text { Mild } \\
\text { imbalance }\end{array}$ & $0.80 \sim 0.89$ & $\begin{array}{c}\text { Good } \\
\text { coordinati } \\
\text { on }\end{array}$ \\
\hline $0.40 \sim 0.49$ & $\begin{array}{l}\text { Border on } \\
\text { imbalance }\end{array}$ & $0.90 \sim 1.00$ & $\begin{array}{c}\text { Quality } \\
\text { coordinati } \\
\text { on }\end{array}$ \\
\hline
\end{tabular}
intuitively. The specific division is shown in Table 1.

Table 1 Evaluation Standard of Coupling Coordination Degree

\section{Coupling Coordination Model}

1. Indicator Construction

The construction of an indicator system should follow the principles of scientificity, systematism, and data availability. Under this principle, an indicator system that reflects the coordinated and coordinated development of tourism development and poverty alleviation effects is constructed. Based on the concept of sustainable tourism development, referring to the sustainable development evaluation indicators established by the United Nations Commission on Sustainable Development and other institutions, the above-mentioned DPSIR quality evaluation model is introduced, which comprehensively considers the interaction between the indicators of each link, which can be more in-depth and detailed Describe the operation process of the tourism 
development system. This method provides basic and effective model support for domestic and foreign scholars to research resources, environment, socio-economic and other aspects.

Because of the complex nature of the tourist destination ecosystem, the strong comprehensiveness and high relevance of the tourism industry, under the framework of the five major systems of the driving force, pressure, state, impact, and response, the indicators of poverty alleviation in this paper mainly refer to the research of relevant scholars Results [10], select representative indicators of each of them for quantitative analysis; and tourism development indicators are mainly constructed by referring to existing research results [11], and combining with statistical yearbook data of Guizhou Province.

According to the DPSIR conceptual framework model of tourism development in Fig. 1, the complexity of the model is evaluated from the process complexity. The sum of the complexity of the judgment conditions of each process node is defined as the flow complexity of the node. The product of the number of judgment items of each judgment condition and the logical complexity of the judgment condition is defined as the complexity of the judgment condition, as shown in formula (4)

$C_{N F}=\sum_{i=1}^{N_{C}} C_{C}(i)=\sum_{i=1}^{N_{C}}\left(N_{O C}(i) * L_{O} C(i)\right)$

In the formula, CNF is the flow complexity of a single process node; $\mathrm{NC}$ is the number of judgment conditions of flow; $\mathrm{CC}$ (I) is the complexity of each judgment condition itself; NOC (I) is the number of judgment items of judgment condition; LOC (I) is the logical complexity of judgment condition. Considering the above three factors, the calculation model of process complexity is given, as shown in formula (5)

$M_{F}=V_{F} \sum_{n=1}^{N_{O}}\left(1+C_{N F}(n)\right)$

In the formula, MF is the complexity of a single process; VF is the loop complexity of the process; no is the total number of nodes in the process; CNF (n) is the flow complexity of each node, and its calculation method is shown in formula (4). To simplify the comparison, the flow chart in Fig. 1 is simplified into that in Fig. 3, and the process complexity is 18 according to the formula. The process complexity is at a moderate level in the field of process management.

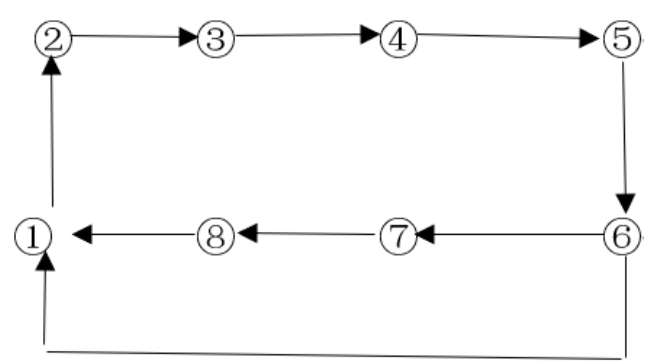

Fig. 3 simplified flow chart

\section{Data Source and Processing}

The data in this paper are from Guizhou Statistical Yearbook (2012-2019), statistical bulletin of national economic and social development in corresponding years of each county (city, district), and government work report. Considering the availability of index data, the evaluation of tourism poverty alleviation efficiency usually adopts the relevant alternative indicators. The foreign exchange income of international tourism, the number of inbound tourists, the number of domestic tourists, the domestic tourism income, the total tourism income, the total number of travel agencies, and the number of tourism service personnel are used to represent the input indicators of tourism development. According to the principle of index selection, eight statistical indicators are selected as the measurement indexes of the poverty alleviation effect system, which are farmers' per capita disposable income, provincial GDP, the number of poor counties, the number of rural employment, the number of rural residents who enjoy the minimum security, the rural social infrastructure income villages (average), the number of poverty alleviation related policies and regulations issued by the state and the number of poverty alleviation related countries Rural minimum living security expenditure. Through the above indicators, the economic benefits and tourism development scale of povertystricken counties (cities, districts) are characterized.

To avoid the influence caused by the difference of the index dimension or the index measurement level, the constructed index system is divided into a positive index and negative index, and they are dimensionless processed according to the nature of the index [12]. The formula is (4) and (5).

When the indicator is a positive indicator:

$u_{i j}=\frac{x i j-\min x i j}{\max x i j-\min x i j}+0.001$

When the indicator is negative:

$u_{i j}=\frac{\max x i j-x i j}{\max x i j-\min x i j}+0.001$

$\mathrm{u}_{\mathrm{ij}}$ is the standardized value of the $\mathrm{j}(\mathrm{j}=1,2, \ldots, \mathrm{n})$ index of the $\mathrm{i}(\mathrm{i}=1,2)$ system, $\mathrm{x}_{\mathrm{ij}}$ is the actual value, $\operatorname{maxx}_{\mathrm{ij}}$ is the maximum value in the index system, and $\operatorname{minx}_{\mathrm{ij}}$ is the minimum value in the indicator system.

3. Evaluation Model of Comprehensive Development Level

Using linear weighting method to calculate the comprehensive development degree of tourism development system and poverty alleviation effect system, The calculation formula is:

$u_{i=1,2}=\sum_{j=1}^{n}$ wijuij 
$\sum_{j=1}^{n} w i j=1$

$\mathrm{u}_{1}$ represents the comprehensive development index of the tourism development system, $\mathrm{u}_{2}$ represents the comprehensive development index of the poverty alleviation effect system, and $\mathrm{w}_{\mathrm{ij}}$ is the index weight.

\section{Determination of Weight}

Generally speaking, the greater the weight of a certain indicator, the greater the role it can play in comprehensive evaluation; on the contrary, the smaller its weight, the smaller the role it can play in comprehensive evaluation. First, assign weights to the indicators, and use the analytic hierarchy process to calculate the weights of the indicators in the tourism development system and poverty reduction effect system in Guizhou Province, as shown in Table 2.

Table 2 Weight of Each Index of The System

\begin{tabular}{|c|c|c|c|c|c|}
\hline $\begin{array}{l}\text { Syste } \\
\mathrm{m}\end{array}$ & $\begin{array}{l}\text { Essent } \\
\text { ial } \\
\text { Factor }\end{array}$ & Indicator & Direction & $\begin{array}{l}\text { Ind } \\
\text { ex } \\
\text { Cod } \\
\text { e }\end{array}$ & $\begin{array}{l}\text { Wei } \\
\text { ght }\end{array}$ \\
\hline \multirow{24}{*}{$\begin{array}{l}\text { Shake } \\
\text { off } \\
\text { Pover } \\
\text { ty }\end{array}$} & \multirow{6}{*}{$\begin{array}{l}\text { Dyna } \\
\text { mics }\end{array}$} & Per Capita & \multirow[t]{4}{*}{ positive } & \multirow{4}{*}{$\mathrm{P}_{1}$} & 0.14 \\
\hline & & Disposable & & & 64 \\
\hline & & Income of & & & \\
\hline & & Farmers /yuan & & & \\
\hline & & GDP of & \multirow[t]{2}{*}{ positive } & \multirow[t]{2}{*}{$\mathrm{P}_{2}$} & 0.13 \\
\hline & & $\begin{array}{l}\text { Guizhou } \\
\text { province/ } \\
\text { billion }\end{array}$ & & & 17 \\
\hline & \multirow{5}{*}{$\begin{array}{l}\text { Pressu } \\
\text { re }\end{array}$} & Number of & \multirow[t]{3}{*}{ negative } & \multirow[t]{3}{*}{$\mathrm{P}_{3}$} & 0.12 \\
\hline & & Poor & & & 52 \\
\hline & & Counties/PCS & & & \\
\hline & & Rural & \multirow[t]{2}{*}{ positive } & \multirow[t]{2}{*}{$\mathrm{P}_{4}$} & 0.13 \\
\hline & & $\begin{array}{l}\text { Employment/p } \\
\text { erson }\end{array}$ & & & 65 \\
\hline & \multirow{6}{*}{$\begin{array}{l}\text { Influe } \\
\text { nce }\end{array}$} & Minimum & \multirow[t]{2}{*}{ negative } & \multirow[t]{2}{*}{$\mathrm{P}_{5}$} & 0.11 \\
\hline & & $\begin{array}{l}\text { Number of } \\
\text { Rural } \\
\text { Residents/ ten } \\
\text { thousand } \\
\text { persons }\end{array}$ & & & 48 \\
\hline & & Income village & \multirow[t]{4}{*}{ positive } & \multirow[t]{4}{*}{$\mathrm{P}_{6}$} & 0.14 \\
\hline & & $\begin{array}{l}\text { of rural } \\
\text { social }\end{array}$ & & & 64 \\
\hline & & infrastructure & & & \\
\hline & & / PCS & & & \\
\hline & \multirow[t]{7}{*}{ status } & Number of & \multirow[t]{6}{*}{ positive } & \multirow[t]{6}{*}{$\mathrm{P}_{7}$} & 0.10 \\
\hline & & $\begin{array}{l}\text { policies and } \\
\text { regulations on }\end{array}$ & & & 53 \\
\hline & & poverty & & & \\
\hline & & alleviation & & & \\
\hline & & issued by the & & & \\
\hline & & state/ PCS & & & \\
\hline & & National & positive & $\mathrm{P}_{8}$ & 0.09 \\
\hline
\end{tabular}

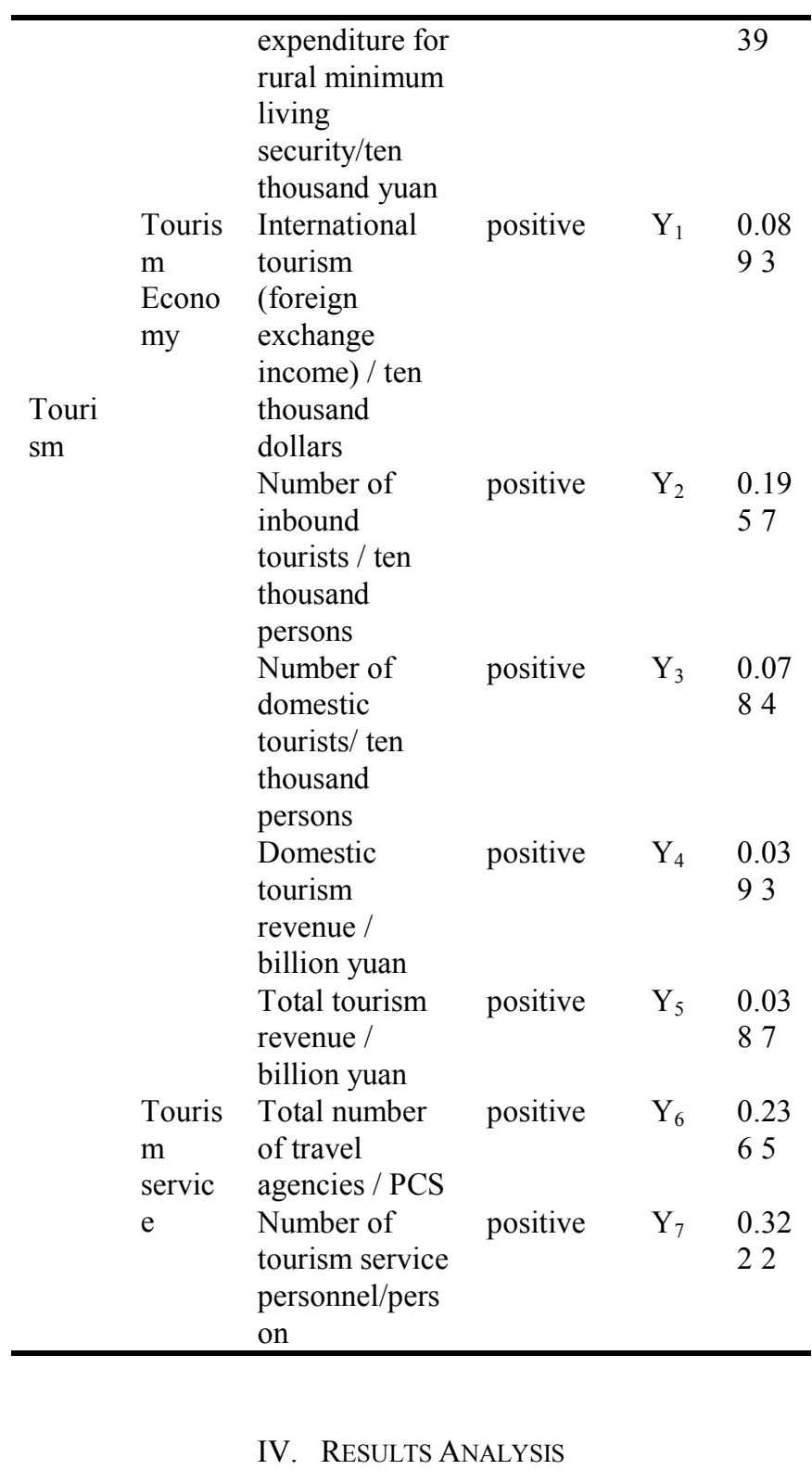

According to the coupling degree model and the coupling coordination degree model, the comprehensive development indexes $\mathrm{u}_{1}, \mathrm{u}_{2}$, coupling degree $\mathrm{C}$, comprehensive evaluation index $\mathrm{T}$, and coupling coordination degree $\mathrm{D}$ of Guizhou tourism development system and poverty reduction effect system from 2012 to 2019 can be obtained And classify the coupling coordination level according to the results. The specific results are shown in Table 3 and Fig. 3.

Table 3 Coupling degree and coupling coordination degree table

\begin{tabular}{|c|c|c|c|c|c|c|c|}
\hline $\begin{array}{l}\text { Ye } \\
\text { ar }\end{array}$ & $\mathrm{u}_{1}$ & $\mathrm{u}_{2}$ & $\begin{array}{l}\text { Couplin } \\
\text { g value } \\
\text { (C) }\end{array}$ & $\begin{array}{l}\text { Coordin } \\
\text { ation } \\
\text { Index } \\
(\mathrm{T})\end{array}$ & $\begin{array}{c}\text { Coupling } \\
\text { Coordination } \\
\text { value (D) }\end{array}$ & $\begin{array}{c}\text { Grad } \\
\text { e }\end{array}$ & $\begin{array}{c}\text { Couplin } \\
\mathrm{g} \\
\text { Coordi } \\
\text { nationd } \\
\text { egree }\end{array}$ \\
\hline $\begin{array}{l}20 \\
12\end{array}$ & $\begin{array}{c}0.183 \\
2\end{array}$ & $\begin{array}{c}0.00 \\
00\end{array}$ & 0.0000 & 0.0920 & 0.0000 & 1 & $\begin{array}{c}\text { Extrem } \\
\text { e imbal } \\
\text { ance }\end{array}$ \\
\hline
\end{tabular}




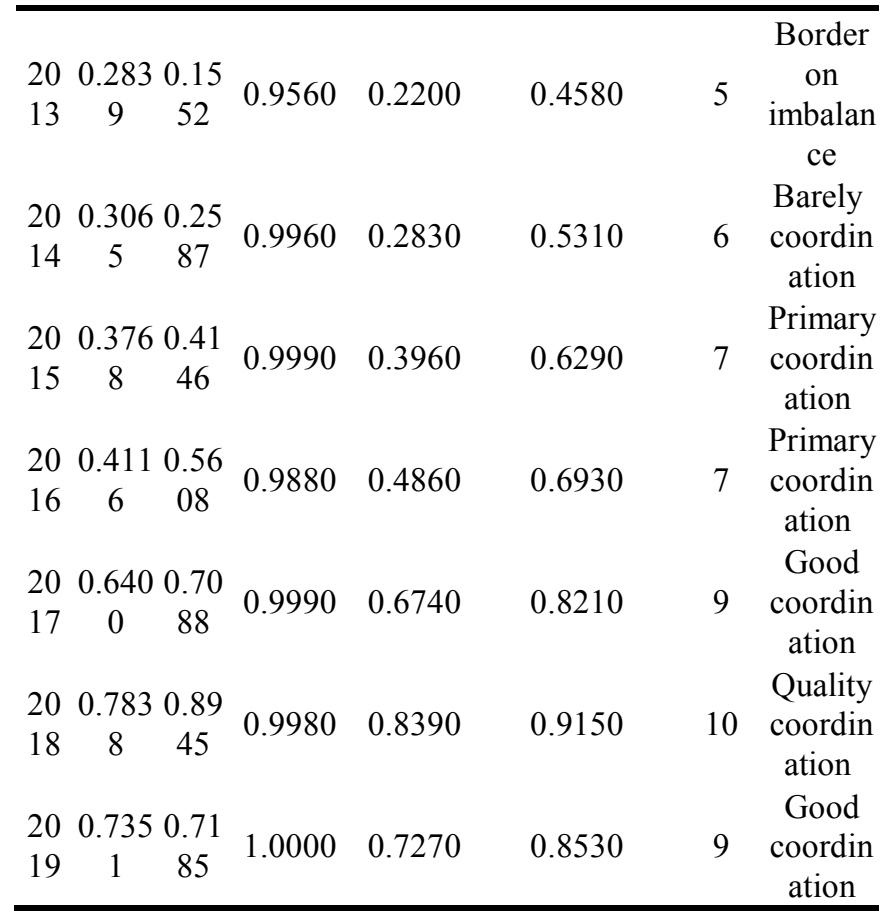

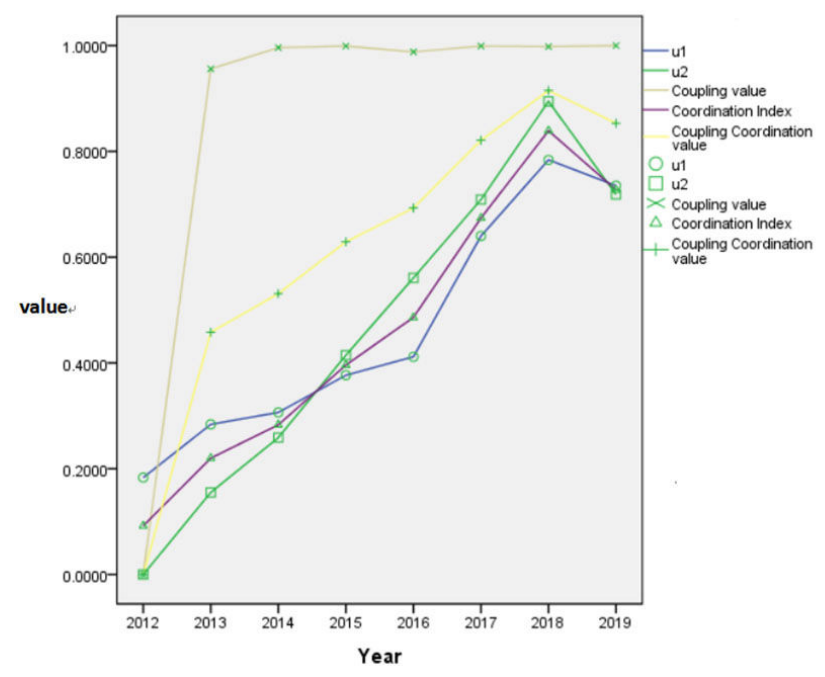

Fig. 4 Coupling and coordination results

According to Table 3 and Fig. 3, the coupling and coordinated development level of tourism development and poverty alleviation efficiency in Guizhou Province from 2012 to 2019 show an overall growth and rising trend. The growth of tourism development system evaluation index $\mathrm{u}_{1}$ is slower than that of poverty alleviation efficiency evaluation index $\mathrm{u}_{2}$, which is related to the development policies of Guizhou in recent years. The growth rate of $u_{1}$ was slow from 2012 to 2016, showing a rapid growth state from 2017 to 2018, and a downward trend after 2018. $\mathrm{u}_{2}$ shows a linear growth trend from 2012 to 2018 and a downward trend after 2018. The values of $\mathrm{u}_{1}$ and $\mathrm{u}_{2}$ were the highest in 2018 , which were 0.7838 and 0.8945 respectively. The change of $u_{1}$ and $u_{2}$ index values is closely related to the rapid development of the national economy in Guizhou Province and a series of government's important tasks of poverty alleviation and Rural Revitalization. From the perspective of coordinated development of the tourism development system and poverty alleviation efficiency, the value of coupling degree $\mathrm{C}$ increased rapidly to 0.9560 from 2012 to 2013 and showed a steady and slow growth trend from 2014 to 2019. From 2012 to 2018, the coupling coordination degree $\mathrm{D}$ value slowly increased to the highest value of 0.9150 , which means that the coordinated development degree of the two systems has reached the level of high-quality coordination.

In conclusion, the comprehensive development index of the Guizhou tourism development system from 2012 to 2014 is higher than the comprehensive development index of the poverty reduction effect system, indicating that Guizhou tourism is at the stage of intensive development at this stage, but the effect on poverty reduction is still Bad condition; the comprehensive development index of the tourism development system from 2015 to 2019 is lower than the comprehensive development index of the poverty reduction effect system, indicating that the effect of poverty reduction is better at this stage, and the comprehensive development index of the tourism system also shows an upward trend. From 2012 to 2019, the coupling and coordination level of Guizhou's tourism development system and poverty alleviation effect system changed from a severe imbalance to good coordination, indicating that the coupling and coordination development of the two is better.

\section{A. The Development Level of Tourism Development} System and Ecological Environment System in Guizhou Province

It can be seen from Table 3 and Fig. 3 that the comprehensive index of the tourism development system and poverty alleviation effect system in Guizhou Province has shown an overall upward trend from 2012 to 2019, especially from the perspective of the development trend of tourism development system u1. The development is fluctuating and rising at a faster rate. This is because Guizhou Province has actively carried out poverty alleviation from various aspects in recent years. At the same time, development has relied on the province's tourism resources to attract many domestic and foreign tourists. A transit station for tourism, the tourism industry is developing rapidly. Although $\mathrm{u} 1$ decreased by about 0.0487 in 2019 compared to 2018 , it can be seen that Guizhou's tourism industry is developing rapidly, especially in 2013. 2013 is the first year to promote the construction of the "100 tourist scenic spots" platform, and major events are held The convention and exhibition activities have promoted the indepth development of the tourism economy. Various regulations and measures have promoted the development of the tourism industry in Guizhou Province. By 2019, the development of the tourism industry will be in a good and stable state. The poverty alleviation effect index u2 decreased by about 0.176 in 2019 compared with 2018 . At this stage, the good results achieved gradually stabilized, so the development rate was slightly slower. Guizhou Province established a 
special agency for poverty alleviation and development office to promote the good progress of poverty alleviation and development work in Guizhou Province and win the tough battle of poverty alleviation. By 2018, u2 reached 0.8945 . The development of tourism is faster than the effect of poverty alleviation. Relevant policies have promoted the fight against poverty and pushed Guizhou's poverty alleviation work to a new level. In 2019, we can see from the index that poverty alleviation work has achieved certain results and entered the consolidation phase.

\section{B. The Coupling and Coordination Degree of Guizhou} Tourism Development System and Poverty Alleviation Effect System

It can be seen from Table 3 and Fig. 3 that the coupling degree of the two also increases year by year, and the coupling coordination level has developed from a serious imbalance in 2012 to primary coordination in 2014. According to the data in Table 3, the coupling coordination level can be divided into three stages: (1) The severe imbalance period in 2012 to the imminent imbalance period in 2013, the coupling coordination degree developed from 0.1668 in 2012 to 0.4580 in 2013 At this stage, Guizhou Province has gradually realized the importance of the development of tourism and poverty alleviation, but the tourism industry is still not well-developed, and the effect of poverty alleviation is not obvious. Obvious dysregulation; (2) From 2014 to 2016, the coupling coordination level experienced a dynamic change process from the imminent dysregulation period to the primary coordination period. At this stage, the effectiveness of relevant policies in Guizhou Province is being highlighted, and tourism development has also experienced a recovery growth phase and In the development stage, the mutual promotion of the tourism development system and the ecological environment system has been significantly improved; (3) The primary coordination period in 2017 to the high-quality coordination period in 2018 and then the good coordination period. At this stage, tourism development is developing rapidly and the effect of poverty alleviation Better, and entered the consolidation phase. However, according to the data in Table 3 , it can be seen that the coupling coordination level in 2019 has changed from a high-quality coordination period to a good coordination period. It can be seen that in the future, Guizhou Province should still pay attention to tourism development and achieve stable poverty alleviation, and actively realize the mutual promotion of the two.

\section{CONCLUSION AND INSPIRATION}

\section{A. Research Conclusion}

(1) The comprehensive development indexes $\mathrm{u} 1$ and $\mathrm{u} 2$ of Guizhou's tourism development system and poverty alleviation effect system have developed steadily from a lower level to a higher level.

(2) From 2012 to 2019, the coupling coordination level of Guizhou's tourism development and poverty alleviation effect gradually developed from severe imbalance to imminent imbalance, primary coordination, good coordination and highquality coordination to good coordination, and the mutual promotion between the two systems The role is strengthened, and the trend of coordinated development and optimization is obvious.

(3) The coupling and coordination of the tourism development system of Guizhou Province and the poverty alleviation effect system show an alternating development as a whole. Based on the vigorous development of the tourism industry in Guizhou Province, Guizhou Province actively wins the battle of poverty alleviation and uses this Sustainable development to drive local economic development and improves infrastructure. These measures have achieved a certain degree of good development of poverty alleviation work, and effectively promoted the coordinated development of the two.

\section{B. Research Implications}

From 2012 to 2019, the coupling and coordination of tourism development and poverty alleviation effects in this poverty-stricken area in Guizhou Province successfully achieved the evolution from severe imbalance to good coordination. Although its evolution path and evolution trajectory are difficult to replicate, its experience is still worth learning and promoting, details as follows.

(1) Build an interactive and win-win mechanism to promote the coordinated development of tourism development and the effect of poverty alleviation. Tourism development has a supportive effect on the development of poverty alleviation, and poverty alleviation also has a restrictive effect on tourism development. Tourism development not only promotes poverty alleviation but also has a coercive effect. The development of tourism, especially the development of tourism in povertystricken areas, its particularity, and vulnerability make the interaction between tourism development and poverty alleviation more obvious. To achieve an interactive and winwin mechanism for the mutual promotion of the two, we should give full play to both the Promotion effect and support effect, weakening the stress effect and restraint effect of the two.

(2) Optimize the structure of tourism development and promote the development of a complex ecosystem with smart tourism, global tourism, and ecotourism as the main body. Eventually, a complex ecosystem of economic, social, and natural environmental cycles will be established. To achieve this goal, tourism enterprises should try their best to promote the development of poverty-stricken rural areas and win the battle against poverty as soon as possible.

(3) To clarify the coupling relationship between tourism development and poverty alleviation efficiency is of great practical significance and theoretical value for improving the efficiency of regional tourism poverty alleviation, accelerating regional economic development, and helping the poor people get rid of poverty and become rich. It provides scientific reference and practice mode for formulating tourism Poverty 
Alleviation Policies and improving relevant systems.

(4) Strengthen the cooperation mechanism of the poverty alleviation department and select tourism resources that highlight local characteristics. Although the Wuling Mountain Area is connected by mountains and rivers and has many similarities in different regions, it still has its characteristics due to ethnic differences, cultural differences, and population differences in the location. Because the poverty alleviation departments of different counties work according to the functions of the region, it may cause many problems such as cooperation difficulties in the poverty alleviation departments. Therefore, when transforming tourism resources, attention should be paid to maintaining cooperation of the county departments, selecting resources that highlight their characteristics, and condensing characteristics To achieve differentiated development of tourism from other regions, we must accelerate the progress of poverty alleviation and improve the efficiency of poverty alleviation based on taking into account both the efficiency of poverty alleviation and the quality of poverty alleviation. $\square$ Strengthen the construction of transportation facilities in poor areas. $\square$ Strengthen the construction of communication and network facilities in poor areas. $\square$ Infrastructure should be reasonably configured to improve resource utilization. The implementation of poverty alleviation tourism must not only strengthen the construction of infrastructure, but also pay attention to the rationalization of facility allocation, and the rational allocation of resources may improve the efficiency of poverty alleviation. Reasonable optimization of allocation can not only improve the economic benefits of poverty alleviation in each county but also play a positive role in promoting its future development.

(5) Strengthen research and monitoring of the coordinated development of tourism development and poverty alleviation. The coupling and coordination between tourism development and poverty alleviation effect is an alternating development process. Strengthen the research and monitoring of the coordinated development state of tourism development and ecological environment, and promote the development of the two towards the optimal coordination state. The government and relevant departments must not only conduct research and evaluation before tourism development but also follow-up feedback in the process of tourism development to ensure the coordination and sustainable development of tourism development and poverty alleviation. Relying on the transformation of tourism resources, we will improve the coordinated development management system for tourism development and poverty alleviation.

Based on the above conclusions, there are still some deficiencies in this paper: there is no statistical caliber for the coordinated development of tourism and poverty alleviation in China's current statistical data. Due to the availability of index data and the uncertainty of the stripping coefficient, the tourism poverty alleviation output is difficult to be separated from the whole national economic output, so we can only select alternative indicators to evaluate the coordinated development of tourism development and poverty alleviation efficiency 。 The results are scientific and reflect the current situation of regional tourism development and poverty alleviation efficiency. If the relevant statistical caliber is gradually improved or the stripping coefficient is determined in the future, the coupling and coordinated development index system of tourism development and poverty alleviation efficiency can be further optimized to make the measurement results more scientific and reliable. The follow-up research can also deeply analyze the impact of a coupling degree in time and space. To construct the ecological early warning mechanism of tourism industry development, relevant government departments should strengthen the research and monitoring of the development status of tourism development and poverty alleviation efficiency according to laws and regulations, to promote the development of the two towards the optimal coordination state. The government and relevant departments should not only carry out investigation and evaluation before tourism development but also track and feedback in the process of tourism development, to ensure the coordination and sustainable development of tourism development and poverty alleviation.

\section{ACKNOWLEDGMENT}

This study was supported by Science and technology cooperation project of Guizhou Province, China "Research on the simulation design of 'Intelligent Tourism' management system -- Taking Chishui scenic spot as an example" (Grant No. Qian Ke He LH Zi [2016]7025]).

\section{REFERENCES}

[1] J. P. Xi, "Decided to build a well-off society in an allround way and seize the great victory of socialism with Chinese characteristics in the new era," People's Daily, vol. 10, pp. 28, 2017.

[2] J. Zhang, and Y. Meng, "Influencing factors and realization mechanism of the coupling development of modern agriculture and new urbanization," Product. Res., no. 3, pp. 41-42, 2016.

[3] F. Yu, "Research on precise poverty alleviation strategies based on the concept of green development," Western Forum, vol. 28, no. 1, pp. 84-89, 2018.

[4] Z. Tang, Y. Ma, M. Liu, et al., "Research on the multisubject symbiosis of ethnic tourism communities based on the common trust of the government," Regional Res. Dev., vol. 37, no. 1, pp. 114-119, 2018.

[5] H. Li, and Q. Wang, "Research on Performance Evaluation of Yunnan Rural Ecological Poverty Alleviation Project Based on SBM-DEA Model," Ecol. Econ., no. 8, pp. 133-138, 2018.

[6] C. Liao, "Quantitative Evaluation and Classification System of Coordinated Development of Environment and Economy-Taking the Pearl River Delta Urban Agglomeration as the," Trop. Geogr., no. 1, pp. 12-16, 1999. 
[7] S. Li, and M. Li, "Research on the coupling relationship between tourism economy and ecological environment of coastal cities in China," Bus. Res., no. 2, pp. 185-192, 2016.

[8] L. Wang, J. Su, and J. Huang, "Analysis on the coupling coordination degree of tourism economic development and ecological environment of Forest Park in Shanxi Province," Agric. Tech. Econ., no. 8, pp. 98-104, 2013.

[9] Y. Fang, Z. Huang, DZ, et al. "Study on the coupling and coordination of tourism development and ecological environment in China," Econ. Geogr., no. 12, pp. 195201, 2013.

[10]X. Chen, "Multiple Couplings: A Path to Accurate Poverty Alleviation in the Context of Rural Revitalization]," Guizhou Soc. Sci., no. 3, pp. 155-159, 2019.

[11]N. Gao, Y. Ma, T. Li, et al., "Tourism industry based on the coupling model and Research on the Coordinated Development of Urbanization-Taking Xi'an as an Example," Tourism Trib., no. 1, pp. 62-68, 2013.

[12]X. Shu, Y. Gao, Y. Zhang, et al., "Study on the Coupling Relationship and Coordinated Development of Tourism Industry and Ecological Civilized City," China Populat. Resour. Environ., no. 3, pp. 82-90, 2015.

Yanling Ma has gained the master's degree of management. She graduated from the Harbin Institute of Technology in 2015. She is a lecturer in Zunyi Normal College. Her research interests include tourism management and social governance.

\section{Creative Commons Attribution License 4.0} (Attribution 4.0 International, CC BY 4.0)

This article is published under the terms of the Creative Commons Attribution License 4.0 https://creativecommons.org/licenses/by/4.0/deed.en_US 